Archaeological Journal

\title{
Notes On The Priory Of Dartford, In Kent
}

\author{
the Rev. C. F. R. Palmer
}

To cite this article: the Rev. C. F. R. Palmer (1882) Notes On The Priory Of Dartford, In Kent, Archaeological Journal, 39:1, 177-179, DOI: 10.1080/00665983.1882.10852030

To link to this article: http://dx.doi.org/10.1080/00665983.1882.10852030

曲 Published online: 14 Jul 2014.

Submit your article to this journal

Q View related articles $₫$ 


\title{
NOTES ON THE PRIORY OF DARTFORD, IN KENT.'
}

\author{
By the Rev. C. F. R. PALMER.
}

In the thirty-sixth volume of the Archceolorical Journal for 1879 appeared a History of the Priory of Dartford, in Kent, belonging to the Sisters of the Second Order of St. Dominic. The account of that monastic establishment embraced in main outline all that had been gathered chiefly at the Public Record Office and the Library of the British Museum. A very recent residence for some months at Rome has afforded both opportunity and leisure for extensive researches in the Archives of the Master - General of the Dominicans, to which the kindness and liberality of the present head of the Order, F. Jose Maria Larroca, gave free and unlimited access. The registers of generals bring to light fresh facts in the later history of this Priory, which possess at once, interest, as they cannot be found in the national records; and value, as they disclose important events, adjust one or two trifling inaccuracies, and even afford a glimpse behind the grill into the discipline of monastic seclusion.

There are no original registers of the masters now existing in these archives more ancient than the year 1474. Political crises and revolutions probably scattered and eventually destroyed the earlier records : even those which are still preserved had a very narrow escape of loss, in 1870, when the Piedmontese occupied Rome, and made it the capital of Italy.

\section{Extracts from the Registers of the Masters-General.}

1474, June 27th. Sister Beatrice, Prioress of Dartford, has licence to use linen "propter debilitatem et antiquitatem ;" to dispose of, and dispense within the Order, the goods conceded to her use by the Order; and to give alms.

1481, June 19th. Sister Anne Barn, prioress, may choose the confessor for her monastery, and he cannot be forced to a priorship : a president may be given them by the provincial, with their consent; the subprioress may be absolved and deposed, notwithstanding any other authority; and servants and workmen may enter the monastery without detriment of fame or honour.

Same date. Sister Jane Tyrcllis (sic) may talk in the common speakplace with friends of honourable fame, and without a companion, and

1 Read at the Monthly Meeting of the Institute, 4 May, 1882. 
cannot be removed by her sub-prioress, who educated her ; and in time of sickness is exempted from the service of the choir.

Same date. Sister Jane Fitzh'er, "nobilis et generosa," may have a preceptor in grammar and the Latin tongue; and he may enter the common locutorium (speak-room). Also she and other gentlewomen may be called to learn.

1489, July 4th. All things are confirmed which the provincial has done about the absolution of Sister Alice from the office of prioress, and the confirmation of Sister Elizabeth Crescener as prioress.

1500, May 11th. Sister Giana (Jane?), a nun, may be thrice absolved in all those cases wherein the master-general has power ; and she may speak at the grill with relatives and friends being persons of no blame.

1501, June 2nd. Master Nicholas Stremer is instituted provincial; and, according to custom, may allow blameless women to enter the convents of Sisters.

- June 6th. Sister Cresner may choose a confessor of the Order, and be absolved once a-year, "et si placuerit pleratis (prælatis?) pluries."

1502 (about end of May.) The provincial, F. Nicholas Stremar, may absolve and confirm all priors and prioresses, and especially the prioress of Dartford; and the letters of Master Joachim ${ }^{1}$ are revoked, if they have anything to the contrary.

1503, Jume 8th. The nuns of England may not retain secular women within their monastery; and the provincial may bind them to this order by all means.

The Registers from 1513 to 1520 are wanting and those from 1520 to 1524 very scanty and deficient.

1527, July 23rd. The concession made to Sister Elizabeth Cresner by $F$. Antoninus de Ferraria, formerly vicar of $F$. Master-General Carsias, ${ }^{2}$ is confirmed, that she may receive any well-born matrons, widow of good repute, to dwell perpetually in the monastery, with or without the habit, according to the custom of the monastery ; and also that she may receive young ladies, and give them a suitable training, according to the mode heretofore pursued.

Sister Elizabeth before mentioned, at her own supplication, is absolved from the office of prioress; and the vicaress is instituted (with the authority which sub-prioresses have on the death or removal of a prioress) whom she names. The vicaress, however, may not administer the temporalities of the monastery, without the counsel of four mothers nominated by the same Sister Elizabeth, until a prioress is elected and confirmed; and after the confirmation the authority of the vicaress and consultive mothers shall expire. Sister Elizabeth may also execute last wills, provided only it be for the good of religion. (If she ever actually resigned her office, it is evident that $\mathrm{S}$. Elizabeth Cresner was speedily reinstalled.)

(Shortly after this time the communication between the English province and the Master-general was cut off; and in 1538-9, the province was scattered and destroyed.)

${ }^{2}$ F. Joachinus Turrianus. MasterGeneral from 1487 to 1500 . His register for England from 1494 to 1496 is blank,
${ }^{2}$ F. Garcias de Loyssa, Master-Generql from 1518 to 1524 , 
1560, May 7th, To the lady nun Elizabeth Crener is committed the charge of true prioress, in spiritualities and temporalities as she had in England, over all the sisters exiled with her in Zeeland. She and her companions may be incorporated either in the province of France or Lower Germany, wherever they find benevolent nuns of the Order to take them in. They may take the government of the convent of Leliendael, if committed to them by the provincial and fathers of the province of Lower Germany, with the consent of that convent, in which, it is asserted, there are only four nuns. In case of their not being received there, they are assigned anywhere, at their own pleasure and the disposition of the consuls of the Catholic King.

1567, Jan. 1st. As the English nuns exiled in Zeeland for the faith are deprived of their vicar and confessor by the death of F. Richard Hargrave, and have no father of the Order who speaks their language, they may confess to Henry Folifus, Dean of Bristol, ${ }^{1}$ also in exile there. To him is given all the authority for administering the sacraments to them, which F. Richard had. Also the prioress may dispense with the nuns labouring under any sickness, for the use of linen.

- June 30th. At the petition of the nuns, the care of their temporalities is committed to the charge of the same dean ; or if he is prevented to another nominated by him and at their pleasure.

1574 (beginning of Jan.) The prioress and mothers of Engelendael are ordered to receive charitably into their monastery the three surviving nuns out of England, and the latter are to betake themselves thither.

1 Henry Jolliffe, S.T.B., was installed Dean Sept. 9th, 1554, and was deprived in 1558. 